Estudios Públicos 162 (202I), I-25

DOI: https://doi.org/I0.38178/07/83089/1904200 I I9-e

Article

\title{
Doomed to Repetition? Havana, Washington, Miami, and Moscow, from the Cold War to Today
}

\author{
Radoslav Yordanov \\ Harvard University, United States
}

\begin{abstract}
This paper offers a broad historical overview of US economic sanctions against Cuba, starting with the imposition of the partial trade embargo on 19 October 1960, taking the story up to the present day. Additionally, it develops a comprehensive survey of the numerous scholarly and policy debates which closely follow the changes in United States' post-Cold War attitudes and actions towards its southern neighbor and which demonstrate the thinking behind centers of power in Washington and Miami related to US' Cuba policies. The paper also glances over the latest developments under Cuba's new President Miguel Díaz-Canel and the notable return to the harsh Cold War rhetoric, which transcends the boundaries of the localized Washington-Miami-Havana axis of the past 30 years. Referring to historic patterns, the paper concludes that the conjecture between the recent complication in the US-Cuba relations and Moscow's ambition to reinstate its erstwhile position as an unavoidable international factor would afford Havana with the opportunity to reclaim once again the dubious honor of becoming one of the focal points in the renewed competitive coexistence between the United States and Russia.
\end{abstract}

KeYwords: Cuba, Soviet Union, Russia, United States, Cold War, economic sanctions

ReCEIVED: January 2020 / ACCEPTED: June 2020

Radoslav Yordanov is PhD in History, Oxford University. Researcher at Davis Center for Russian and Eurasian Studies, Harvard University. Address: 1730 Cambridge Street, 3rd Floor, Cambridge, MA 02138. Email: radoslav.yordanov@sant.oxon.net. 
$\mathrm{n}$ the twenty-first century, international economic sanctions became one of the central instruments of global governance, and Washington increasingly came to perceive them as an almost instantaneous and easy way of furthering US interests on the challenging post-Cold War global scene (Lanvin 1996, 153). Consequently the number of sanction regimes grew considerably. While in the 1950s only five countries were subjected to sanctions, by the year 2000 nearly fifty states became targeted (Hufbauer et al 2007, 17). The long-standing US economic embargo against Cuba represents an example of Washington policy-makers' continuing belief in the usefulness of economic sanctions, regardless of the lack of evidence in support of their effectiveness over the past 60 years (Fisk 2000, 65). Washington's embargo against Havana has consistently demonstrated that as a coercive measure it has failed as the target state has placed a greater value on other priorities besides economic prosperity, such as ideology or nationalism. In return, Havana's continuing resilience has prompted Washington to launch unilateral measures with extrateritorial application of its national legislation. This approach contests the legal equality of the states in international affairs and the principles of respect for national sovereignty and non-intervention in the domestic politics of a foreign country.

US sanctions against Cuba are unique in terms of their long duration as well as in their thoroughness and sophistication. Even by the US government's own admission, "The embargo on Cuba is the most comprehensive set of American sanctions ever imposed on a country" (Lamrani $2013,13)$. While the embargo regime has remained intact since 1960, the dynamics behind Washington's Cuba policy have changed on numerous occasions over the years. As a result, the economic sanctions evolved from a tool to generate regime change into an instrument to promote democracy and foster democratic transition by attempting to exert economic pressure and isolate the island (Badella 2014, 64). For decades, American presidential administrations have portrayed the Cuban regime as isolated and marginalized by the international community for its human rights record. However, while Washington and its European allies appeared to have corresponding interests in Cuba, they have chosen different means to achieve them. The United States has imposed a punitive total economic embargo, whereas the European Union has sought to engage Havana, providing humanitarian aid and developing trade links. 
As a result, it appears that the international community has found, nearly unanimously, that it is the United States, and not Cuba, which has shown little respect for international law and global governance (Dobson and Marsh 2005, 79; Gordon 2012, 75). Consequently, over the course of six decades, the US policy of economic sanctions towards Cuba has failed to achieve its objectives but managed to make Washington look increasingly powerless. Washington's policy toward Cuba contrasts markedly with its policy toward China and other countries accused of human rights violations, demonstrating the double standards in US policymaking and implementation. Accordingly, anti-Americans across the world have used the US embargo against its southern neighbor to expose the "hypocrisy of a superpower" which "punishes a small island while cozying up to dictators elsewhere" (Naím 2009; Schwab 1999, 17).

There has been considerable deterioration in the US-Cuba relations under President Trump following the thaw initiated by President Obama and the Cuban leader Raúl Castro in 2014. Accordingly, this paper offers a broad historical overview of US economic sanctions against Cuba, starting with the imposition of the partial trade embargo on 19 October 1960 and taking the story up to the present day. It also uses a wide range of primary sources dealing with Soviet bloc's rush to assist Cuba against the US punitive economic move, which was instrumental in enabling and prolonging Cuba's defiant stance against its mighty adversary, much in the vein in which in the post-Cold era Western Europe, Latin America, and China stepped in to replace the lost Socialist bloc commercial and aid connections. Additionally, it provides a comprehensive survey of the numerous scholarly and policy debates which closely follow the changes in United States' post-Cold War attitudes and actions towards its southern neighbor which demonstrates the thinking behind power centers in Washington and Miami. Ultimately, it glances over the latest developments under Cuba's new President Díaz-Canel and the return to the harsh rhetoric of the Cold War, which transcends the tensions along the Washington-Miami-Havana axis of the past 30 years, allowing Havana to reclaim the questionable reputation of becoming once again a focal point in the renewed competitive coexistence between the United States and Russia. Ultimately, by looking into the latest tightening of the Cuba embargo following the tracing of the complex history of the existing US sanction regime against the Caribbean nation, this paper aims to under- 
stand why today's conservative-minded US politicians, who are steering Washington's Cuba policy, have failed to learn from the numerous important history lessons of the past half-century and continue to employ a coercive foreign policy tool whose effectiveness has been compromised over the past 60 years. In so doing, it ultimately seeks to re-invigorate theoretical and practical discussions for the formulation of unilateral extraterritorial foreign policies, particularly in the time of seismic geopolitical reconfigurations and erosion of various democratic regimes witnessed today.

In the opening section, we trace the evolution of the US trade embargo against Cuba since its inception through the end of the Cold War. Next, we look into the US foreign policy changes in the post-Cold War world and introduce the Cuban American National Foundation. The following section addresses the dynamically changing policies toward the island under the administrations of Clinton, Obama, and Trump. Then, we outline Cuba's reform answers to the fluctuating dynamics of the US embargo under Raúl Castro and Miguel Díaz-Canel, and we finally look at the resurgence of Cuban-Russian relations following the re-tightening of the US embargo in June 2019. In the Addendum, we note the immediate effects of the Coronavirus pandemic on the island and its unparalleled push of domestic economic reforms.

\section{Cold War, warm seas}

Prior to the Cuban Revolution, 70 percent of the island's commercial exchange was with the United States, so at the time of Castro's ascendance to power, the main branches of the country's economy depended totally on US equipment (CGED/MINREX 1981, 4). Following a modest opening of trade relations with the Soviet Union in 1959 and early 1960, the situation markedly changed with the harsh economic warfare which broke out between Cuba and the United States in the summer of 1960. Efforts to make the Cuban economy a socialist one required moral, political and, most of all, economic assistance from the Soviet Union (AJ 1960, 3). Simultaneously, relations with the United States worsened dramatically. On 2 January 1961, Cuba demanded that Washington reduce its diplomatic personnel in Cuba to eleven. After consulting with President-elect John F. Kennedy, President Dwight D. Eisenhower broke diplomatic rela- 
tions with Cuba the next day (Yaffe 2009, 28; Martínez-Fernández 2014, 70-71).

Soviet oil rather than Cuban sugar was the main reason that prompted Washington to take economic action against the island ( $\mathrm{Hu}$ berman and Sweezy 1969, 68-69; LeoGrande and Kornbluh 2014, 36). As part of the trade agreement signed by Soviet Deputy Prime Minister Anastas Mikoyan and Fidel Castro in February 1960, the Soviets sold Cuba crude oil in exchange for sugar. As the CIA observed, the Soviet Union shifted some of its long-term non-socialist state commitments in order to free tankers to supply whatever amounts of oil Cuba needed (CIA $1960,1)$. In response, after the arrival of the first Soviet oil tanker in Cuba on 19 April 1960, on 3 July, Congress authorized the US government to cut Cuba's sugar quota. Two days later, Cuba's Council of Ministers announced that US industrial, banking and commercial operations in Cuba would be expropriated, with owners compensated with long-term government bonds in pesos. On the next day, President Eisenhower introduced economic sanctions against Cuba, canceling the remaining 700,000 tons of sugar imports from the 1960 quota. Moscow responded swiftly and on 20 July offered to buy the sugar which Washington had refused to purchase. In retaliation, the Cubans seized the three largest US sugar mills on the island, further increasing tensions with its northern neighbor.

By the end of July, the Cuban National Institute for Agrarian Reform (Instituto Nacional de Reforma Agraria, INRA) had already taken millions of acres of land, and without much fanfare, Guevara announced that the Cuban Revolution was 'Marxist' (LeoGrande and Kornbluh 2014, 36; Coltman 2003, 172-173). On 17 September, three US banks and their branches and dependencies in Cuba were seized. The United States responded with a partial trade embargo on 19 October, which imposed high economic costs on the Cuban people. Days later, Cuba retaliated by seizing 166 remaining American-owned businesses. The nationalizations of September and October 1960 transferred all sugar mills, 83.6 percent of the industry, 42.5 percent of the land, most of the trade, the banks and the communications networks into state hands. According to the Cuban Ministry of Foreign Trade (Ministerio de Comercio Exterior, MINCEX), the nationalization of the main means of industrial production and banking, together with agrarian changes, eliminated US economic dominance 
and served as the economic basis of the new regime and its socialist reforms (CGED/MINREX 1981, 5). These changes also opened the way for support from the East European socialist states, as a Hungarian foreign ministry's report recommended (MNL 1960, 1).

In these ways, the imposition of the US embargo came to strengthen Castro's legitimacy and brought Cuba closer to the Soviet bloc. In the Cuban foreign ministry's analysis, the "criminal blockade" imposed by the United States forced Havana to seek new markets for its products and new sources of supplies. At the same time, led by the principles of "proletarian internationalism", the Soviet Union and the rest of the socialist states offered Cuba their "fraternal and selfless help" (CGED/MINREX $1981,4)$. As one of the new regime's top economic specialists, Carlos Rafael Rodríguez, noted a decade later that the "economic blockade" ultimately served to orient the island's economy towards the socialist camp; the country dedicated itself to survive heroically against the "brutal acts of US imperialism in the economic, military and political order" (CGED/ MINREX 1972, 4-5). Polish's analysis, the United States, not wanting to accept the independent path of Cuban development, tended to impose its will through "blockade" and force in "flagrant violation of the United Nations Charter," which is the basis of peaceful coexistence among peoples (CGED/MINREX 1962, 1). Washington's economic pressure on Cuba allowed the Caribbean nation and the socialist states to come closer together. Despite the embargo and the United States' proximity, the support of the socialist states helped Cuba to construct a new way of life for its citizens, and serve as an example for the struggle for national liberation of the Latin American countries. The US embargo also helped create "a utopian romantic concept of socialism" in Cuba. Cuba was expected to create an "ideal type of socialism," developed under conditions of "practically wartime blockade." According to one Yugoslav report, Cuban socialism took on some features of "war communism," because it had to defend itself against US pressure and had to overcome Latin American isolation (AJ 1974, 1-2).

In the mid-1970s, however, the potential for an easing of the embargo heightened hemispheric pressure against the US, culminating with the decision of the other members of the Organization of American States (OAS) to lift their sanctions against Cuba on 29 July 1975. In August 1974, National Security Advisor Henry Kissinger advised President 
Gerald Ford that Washington should "loosen up" the embargo if it did not want to "isolate itself" as "Cuba's isolation in the Hemisphere is rapidly coming to an end." At the time, Havana was signing new trade agreements with US' four major NATO allies - Spain, France, Canada, and Great Britain (Schoultz 2009, 262). Similarly, the CIA's Deputy Director for Intelligence, Robert M. Gates, admitted that some of the original impacts of the embargo eroded as Cuba's foreign trade relations became stabilized, with more than four-fifths of Cuban trade going through the Soviet bloc. Together with Western Europe and Japan, the Soviet Union and the East European states become increasingly effective in supplying Cuba with modern industrial equipment. And most of the Latin American states resumed their political and economic relations with Cuba (CIA 1986, 6). Senator Frank Church thought "the wall the United States tried to build around Cuba has crumbled" as the Cuban government maintained regular commercial and diplomatic relations with 86 nations. Cuba's economy did not collapse under the embargo. On the contrary, at home and abroad, Castro had consolidated his position as a "renowned leader." American opposition had "catapulted him into a legendary prominence, as the David who stood off mighty Goliath" (CIA 1977, 5-8).

In August 1975, President Ford lifted the embargo on trade with Cuba by US-owned corporate subsidiaries abroad. Later the president removed the ban on US travel to Cuba and stopped overflights of US surveillance planes, thus laying the foundations to improve bilateral relations. However, in March 1975, Fidel Castro told Soviet newspaper Izvestiya that despite Cuba's economic interest in lifting the "blockade", Havana was not ready to make political concessions to Washington (CSDB 1975a). In Castro's opinion, the removal would primarily benefit the United States. Washington would likely lift the "immoral and unjust measure, bit by bit", by which it would earn "from [a] moral and financial viewpoint" (CSDB 1975b). He admitted Cuba was "in no hurry" and although the "blockade" was harmful to the country, it could wait for another "ten or twenty years" (CIA 1974, 7). For the Cuban leader, while the lifting of the embargo was important, it was nothing more than a friendly gesture. In Fidel's words, it was out of the question for Cuba to choose between the lifting of the "blockade" and the continuation of Cuban trade with the Soviet Union, despite the quality of its goods being inferior to that of the United States" (Levine 2001, 100; CGED/MINREX 1984, 4). Nevertheless, 
from the mid-1980s onwards, Cuba's economic relations with the Soviet Union and all of the European member states of the Council of Mutual Economic Assistance (CMEA) began to deteriorate due to the internal and external economic and political upheaval in the socialist bloc. Although the CMEA was not formally disbanded until 1991, by 1989 its Eastern European member nations, despite their close production relationship with Cuba, had reduced their trade with Havana, at a great cost to the island. In trying to compensate for deteriorating relations with the East, Cuba sought to develop its relations with the developed capitalist states in a bid to expand its international political room for maneuver and to undermine the US economic "blockade" (PAAA 1989, 10). Despite this, a critical Polish report predicted in February 1990 that the upheavals within the CMEA would cause the Cuban economy to collapse within months (IPN 1990, 1). Although it did not collapse, the contraction the Cuban economy suffered from the loss of access to the Soviet bloc, led to one of the deepest economic crises in its recent history. Its northern neighbor saw this as an opportunity to increase its pressure on the Caribbean island.

\section{Enter Cuban American National Foundation (CANF)}

The tense relationship between Havana and Washington outlived the Cold War between the United States and the Soviet Union (Pérez-Stable 2011, 1; Nieto 1999). The dynamics between global power and its much weaker neighbor precede the Cold War. At the turn of the nineteenth century, the United States seldom considered the legitimate national interests of its smaller neighbors, such as Cuba. Nevertheless, the island nation expected developing relations with Washington on an equal footing. Consequently, the United States and Cuba have never managed to develop normal neighborly relations. Washington has always aimed to prevent foreign rivals from getting a foothold in its Caribbean neighbor and has pursued measures through which to translate its objective into policy practice. The conflict between these two strands in US foreign policy towards Cuba found its expression in two congressional amendments passed within three years of each other. The Teller Amendment to the Declaration of War against Spain in 1898 affirmed the U S intention not to annex Cuba. However, the Platt Amendment of 1901 granted 
Washington the right to intervene in Cuba's internal affairs to protect lives and property and preserve Havana's independence (Pastor 1994, 22). At the end of the twentieth century, as in the previous century, the United States thought it viable to demand its right to set the limits for the domestic political regime it would tolerate within Cuba. Therefore, an explanation deep-seated in the rediscovery of historical themes in US regional policy provides a partial explanation of the shifts in Washington's post-Cold War behavior towards its near-neighbors, Cuba in particular (Domínguez 1997, 58-60).

The post-Cold War world also changed the character of US foreign policy priorities and affected the relationship between Washington and Cuba. Executive power became more fragmented, Congress emerged both more engaged and more exposed to political forces in foreign policy, which grew more complicated and diverse. Trade, commerce, finance, and economy assumed a much larger independent role in US foreign policy than they had taken in the Cold-War years (Haney and Vanderbush 2005, 8; Rockman B. 1997, 36). The fractured political setting surrounding Washington's relations with Havana after the end of the Cold War followed the broader changes in US foreign policymaking that followed the collapse of the Soviet Union. These affected not only Washington's interests in a multipolar world but also the role of economic and ethnic interests in US domestic politics. Ultimately, post-Cold War international realities had contradictory effects on Washington and Havana. While the White House saw the end of the Cold War as an opportunity to increase its pressure on the Cuban Revolution, now bereft of the Soviet Union's sponsorship, Cuba was unable to continue its far-reaching foreign policy and export of revolution. As a result, its leaders reoriented Cuba's foreign economic relations towards Latin America and Europe, building friendly ties with former rivals.

With the end of the Cold War, US relations with Cuba became as much an issue of foreign economic policy as one of national security In May 1998 a report by the US Defense Intelligence Agency concluded "Cuba does not pose a significant military threat to the US or other countries in the region". The report found Cuba's military forces to be "residual" and "essentially defensive in nature" (DIA 1998). Despite this conclusion, foreign policy generalists continued to point to Cuba's importance regardless of its small size and a dearth of economic and military power. 
As a foreign policy issue, Cuba touched a broad array of key US national interests, including immigration and security of US borders. A new wave of uncontrolled migration from Cuba would have negative effects on Florida. Furthermore, Cuba continued to maintain an important strategic location in the Caribbean basin by overseeing crucial sea-lanes of communication. An unstable Havana could turn into a new, contagious source of volatility in Washington's backyard either in the form of Cuban emigration, or anti-government intrusions into Cuba from the surrounding islands and Florida (Huntington, S. 1997, 40-42; Muravchik 1992, xiii; LeoGrande 1998, 67).

Owing to the blurrier dividing line between foreign and domestic policy and the more engaged Congress and interest groups (Haass 1997, 114), Robert Putnam's theory of international bargaining as a two-level game (Putnam 1988) offers a fitting explanation of the changes in the US' post-Cold War foreign policy conduct towards Cuba (LeoGrande 1998, 67). By the end of the Cold War, Cuban Americans had acquired significant influence within the US political establishment through a set of institutional channels (Kaplowitz 1998, 206). Starting in the 1980s, the US embargo of Cuba has turned into a mostly domestic policy tool, used more to satisfy the "potent and sometimes fearsome" Cuban lobby than to bring about real political change in Cuba. From being a mere US policy instrument in the 1960s, the Cuban exiles in Miami, and to a lesser extent in New Jersey, started to help shape Washington's Havana policy from the 1980s (Castro 1997, 101-102). CIA veteran, Richard V. Allen, then-President Reagan's national security adviser, conceived the idea that the Cubans in the United States could be effectively organized to promote the White House's aggressive Latin American plans. This provided an impetus for the creation of the Cuban American National Foundation (CANF) (Chardy 1997, A-11). In Miami, its founder, Jorge Mas Canosa justified its inception by citing the need "to take the fight out of Calle Ocho and Miami Stadium [...] into the center of power" (Fonzi 1993, 121). In Washington, Allen claimed that CANF and Reagan's Cuba policy brought about a necessary merger of politics and policy at a time when the presidential administration sought the support of well-organized groups to pressure the Democratic-controlled Congress and the public. As a result, Reagan transferred Cuba policy from Washington to the Cuban American National Foundation in Miami (Landau 2009). 
The Cuban American community was never as uniform as CANF claimed and major cleavages appeared in the 1990s when the collapse of the Soviet Union engendered a humanitarian catastrophe in Cuba. CANF made the same mistake as other exile communities by persistently overestimating its importance and the importance of the embargo to life in Cuba, underestimating the interests of the Cubans living on the island. One of Miami's most serious weaknesses was the concern of the émigrés for family reunification, which gave Havana a potent weapon against Washington (Vanderbush 2009, 303; Skoug Jr 1996, 210). Within Cuban exile circles, the influence of the conservative Cuban Americans steadily declined while the voice of embargo opponents continued to grow, powered by the business community, farmers, religious groups and the younger generation Cuban-Americans (LeoGrande 2019, 8-9). As a result, in 2000 Congress approved a modest easing of the embargo through the Trade Sanctions Reform and Export Enhancement Act, which permitted cash-only sales of US farm products and medical supplies to Cuba. As recent Cuban immigrants had stronger familial bonds, they responded to the opening by increasing in-kind assistance and cash remittances to their families. Although the Cubans who arrived in the United States after 1980 may have rejected Havana's policies, just like those reaching Florida's shores in the 1960s, they placed the well-being of their families first, believing that Washington's punitive policies against Havana were more harmful to their families than to the government (Diaz-Briquets and Perez-Lopez 1997, 417). Once seen as a prerogative of the Office of the President, Washington's relations with Havana acquired an extra dimension, in which the Cuban-American diaspora in southern Florida and New Jersey came to play an instrumental role in the complex calculus that lay behind US Cuba policy.

\section{From Clinton to Trump}

When the Soviet Union collapsed in 1991, Cuba lost its number one trading partner and financial provider. The dire conditions in Cuba during the so-called período especial prompted many in Washington and Miami to conclude that the time was ripe to deliver the coup de grâce to the struggling Cuban government. The United States sought to apply pressure directly to the Cuban people as a way to provoke popular discon- 
tent against the regime. When Fidel did not fall, Congress further tightened sanctions in 1992, passing the Cuban Democracy Act (CDA), which prohibited foreign-based subsidiaries of US companies from trading with Cuba and re-introduced embargo provisions revoked by the Ford administration in 1975 relating to foreign shipping and US overseas subsidiaries' trade with Cuba (Petras and Morley 1996, 269). In mid-October 1992, the author of the bill, Congressman Robert Torricelli (D-NJ), reportedly told a gathering on Cuba at Georgetown University that he wanted "to wreak havoc on that island" (Bardach 1994, 271). Once the bill was signed into law, Secretary of State Warren Christopher called the CDA "one of the most severe sets of sanctions that there is on the books anyplace" (Petras and Morley 1996, 271).

As tough as it was, the Torricelli Act was followed by an even more stringent set of legislative norms against Cuba. On 24 February 1996, a Cuban MiG-29 fighter downed two civilian planes belonging to a $\mathrm{Cu}$ ban-American exile group Brothers to the Rescue that Havana claimed was violating its airspace. Up to the downing of the planes, President Clinton appeared to have successfully resisted congressional attempts to entrench the Cuba embargo policy. However, on March 5, the Senate passed the so-called Cuban Liberty and Democratic Solidarity (LIBERTAD) Act also known as Helms-Burton Act named after its sponsors Senator Jesse Helms (R-NC) and Representative Dan Burton (R-IN). The law instructed the executive to impose extraterritorial sanctions on foreign firms and individuals who engaged in business dealings involving property confiscated from US nationals by the Cuban government. Although Attorney General Janet Reno recommended to Clinton that he veto the law as it undermined presidential constitutional prerogatives (Brenner et al 2015, 26), White House political advisers, who were more concerned about the effect of a potential veto on the president's re-election, prevailed. On 12 March, Clinton signed the Cuban Liberty and Democratic Solidarity Act, which involved multiple efforts to destabilize the revolutionary regime in Cuba.

Ultimately, Clinton's policy towards Cuba left the US more isolated than ever. A 'triumph of politics over policy', the Helms-Burton Act was basically an attempt to internationalize the embargo. As such, it did not hurt the Castro regime itself, but some of Washington's closest commercial allies. Key allies not only refused to support the global reach of US 
national laws but also actively retaliated with counterbalancing domestic measures (Morley and McGillion 2002, 182; Petras and Morley 1996, 272). On 26 August 1996, the other 34 members of the OAS passed a resolution according to which the Helms-Burton Act "does not conform to international law". On 1 October, the Mexican Congress overwhelmingly approved a LIBERTAD Act 'antidote' law that imposed fines of up to US\$ 301,000 on Mexican companies complying with the American legislation. At the end of October, the EU Council of Ministers voted anti-boycott legislation forbidding compliance with the Helms-Burton Act. A month later, the Canadian Parliament passed legislation penalizing companies for obeying US law. The international reaction to the act's extraterritorial character demonstrated that in trade, where globalization works differently than in the political and military fields, the US was not omnipotent (Sanchez 2003, 353; Martínez 1997, 291).

On 4 November 2008, President Barack Obama won Florida without the votes of Cuban American hardliners (Sweig 2008, 241). Similarly, four years later he won nearly half of Florida's Cuban-American vote, which made him better suited than any of his predecessors to begin contemplating an end to the embargo (Sweig and Bustamante 2013, 112). Unlike President George W. Bush, whose Cuba policies were almost entirely aimed at appealing to hardline anti-Castro exiles in South Florida, the ultimate goal of Obama's policy was democracy made in Cuba by the Cuban people, according to their own design, and not for democracy exported from Washington or Miami (Erikson, D. 2011, 101). Across the Straits of Florida, Raúl Castro made it repeatedly clear that Cuba was willing to negotiate with the United States all issues of concern. However, he insisted in a December 2009 speech to the Cuban National Assembly of People's Power that engagement with the United States had to be "based on a respectful dialogue between equals, on any matter, without prejudice to our independence, sovereignty, and self-determination" (Brenner and Castro Mariño 2015, 279).

The rapprochement between the Washington and Havana culminated with the thaw initiated by President Obama and his Cuban counterpart on 17 December 2014, which represented the biggest policy change towards Cuba since Carter's presidency. With it, the US president initiated a new era in the US-Cuba relations that could be considered the beginning of a long path towards 'normalization'. Obama's plan featured 
the reopening of the US embassy in Havana, further relaxation of regulations on travel and remittances to Cuba, and opposition to Congress over the latest legislation on the embargo. "In Cuba, we are ending a policy that was long past its expiration date", Obama said in his 2015 State of the Union address. In early 2016, he took another important step by visiting Havana, the first trip to Cuba by a sitting US president since Calvin Coolidge in 1928 (LeoGrande 2015, 939). However, the rapprochement faced serious opposition from hardline elements among the Cuban-Americans. According to Senator Marco Rubio (R-FL): Appeasing the Castro brothers will only cause other tyrants from Caracas to Tehran to Pyongyang to see that they can take advantage of President Obama's naiveté during his final two years in office. (Jaffe and Labott 2014)

Since his inauguration in January 2016, President Trump has gradually taken a major turn from his predecessor's course. Since the changes are undertaken by Obama in restoring the relations with the island nation in December 2014, the tone of US-Cuba relations has changed for the worse boosting support for the embargo. Driven by older $\mathrm{Cu}$ ban-Americans and those who arrived in the United States after 1980, the Cuban-American community is "divided on the issue of the embargo while still willing to maintain and even expand business relationships established as a result of the Obama initiatives", Florida International University Professor Guillermo Grenier noted in commenting the recent changes in the community's perceptions (Ellis 2019). Trump's policies toward the island took an increasingly hostile tack, evidently motivated less by ideological reasons than by a desire to attract support from Florida's sizable and predominately conservative Cuban-American population at the expense of United States' national interests (Huddleston 2019, 286). On 16 June 2017, the White House issued a National Security Presidential Memorandum, which sought "to promote a stable, prosperous, and free country for the Cuban people" (NSPM 2017), by prohibiting commerce with businesses owned by the Cuban military and security services and banning individual travel to the island. As a result, the spirit of tentative goodwill established after Barack Obama and Raúl Castro restored diplomatic relations almost completely evaporated (Anderson 2019). Months later, to make matters even worse, the Trump administration announced it would pull two-thirds of its embassy staff from Havana after several American and Canadian diplomats suffered hearing loss and 
cognitive impairment, thought to be caused by listening devices planted in the embassy. Havana immediately denied any involvement, urging Washington not to cut diplomatic ties.

Hostility became even more apparent in April 2018, when Trump named the conservative John Bolton to head the National Security Council. This was followed by the appointment of the right-wing Cuban-American lobbyist Mauricio Claver-Carone to run the National Security Council's office of Western Hemisphere affairs in September. A staunch advocate of the US embargo against Cuba, Claver-Carone previously headed the US Cuba Democracy PAC which took over from the CANF the role of the most powerful Cuban exile lobby group in Washington. Following up on his credentials, at the beginning of November, Bolton delivered a poignant speech at Miami Dade College, outlining Trump's hemispheric strategy. Attacking the left-leaning governments of Cuba, Venezuela, and Nicaragua as a "Troika of Tyranny", Bolton claimed that the western hemisphere was once again confronted "with the destructive forces of oppression, socialism, and totalitarianism", vowing US' ambition "to champion the independence and liberty" of its neighbors (White House 2018).

In early June 2019, building on rising tensions, the Trump administration issued new restrictions on American citizens seeking to go to Cuba. Among other things, these prohibited travel there by cruise ships and banned educational or cultural group visits. The restrictions were aimed at punishing Cuba for its support of the embattled Maduro regime in Venezuela. The US Treasury Secretary, Steven Mnuchin, explained the move claiming that:

\footnotetext{
Cuba continues to play a destabilizing role in the Western Hemisphere, providing a Communist foothold in the region and propping up U.S. adversaries in places like Venezuela and Nicaragua by fomenting instability, undermining the rule of law, and suppressing democratic processes. (US Department of the Treasure 2019)
}

Indeed, Mnuchin's language and the intent of the emerging Trump doctrine in Latin America was very reminiscent of Cold War times. In return, economists of the region observed that plunging Venezuelan aid, together with the hardened US trade embargo had created the worst economic crisis Cuba had seen since the special period in the 1990s (Anderson 2019; Radu 2019). 


\section{Reform or sink}

As soon as he assumed provisional power in 2006, Raúl Castro spoke bluntly about Cuba's predicament and in 2010 declared "We reform, or we sink". Facing an aging population, mounting foreign debt and persisting economic hardship at a time of a global downturn, Raúl Castro initiated a process of liberalization of parts of Cuba's state-run economy, including decentralizing the agricultural sector, relaxing restrictions on small businesses, liberalizing real estate markets, easing Cubans' ability to obtain permission to travel abroad and expanding access to consumer goods. In 2014, Cuba's private sector reportedly extended to around 20 percent of the country's workforce. Under Raúl Castro's reform initiative, whether officially designated "social democracy", "market socialism" or "state capitalism", the Cubans embarked on a long path of engineering a socio-economic system "on their own terms" (Sweig and Bustamante 2013, 103). In its foreign economic relations, Cuba seemed less inclined to open up to US businesses, despite its leaders' official claims over the years. At the height of the Cold War, Cuba felt comfortable with Soviet bloc subsidized trade. Following the collapse of the Soviet Union, Cuba's economic survival became increasingly reliant on tourism and nickel extraction, financed mostly by Spanish and Canadian capital, trade with China, and the export of professional services to Venezuela in exchange for oil (Farber 2011, 125; LeoGrande 2000, 1000).

At the same time, US sanctions encouraged Cuba to collaborate with international players that were less friendly to US interests. As part of the efforts to diversify its diplomatic and trade portfolio, Cuba gradually replaced Soviet help with closer relations with Venezuela. In 2000, a cooperation agreement signed between Fidel Castro and Hugo Chavez provided for Venezuelan export of 53,000 oil barrels at subsidized prices in exchange for Cuban health and education services. Cuba also sought to reenlist the help of Moscow. Almost immediately after passing the Torricelli bill into law, in November 1992, Havana concluded a series of trade agreements with Moscow, including a new oil-for-sugar barter agreement, followed by a similar deal in October 1995. On 30 January 2009, Russia and Cuba signed a strategic partnership as part of Russia's push to secure new markets in Latin America. The then Russian President 
Dmitri Medvedev also pledged US\$ 354 million in aid and considered the expansion of "cooperation in agriculture, manufacturing, science, and tourism". In July 2014, under President Vladimir Putin, Russia agreed to write off 90 percent of Cuba's outstanding Soviet-era debts. As far as Beijing was concerned, Cuba represented a small piece of a much larger Latin American puzzle of investment, commodity, energy and natural resource accumulation for the powerful Chinese economy. Under Raúl Castro, Beijing became Havana's second-largest trading partner, exporting electronics, buses, trains, light manufactured goods as well as tourists. Challenging Venezuela's leading position as Cuba's trade partner, Brazil extended a USD\$ 600-million credit line for food and agricultural machinery imports. In January 2014, Brazil's signature investments, the US\$900 million renovations of the port of Mariel, allowed Cuba to benefit from the boom in Caribbean maritime traffic from the expanded Panama Canal. Additionally, Cuba enjoyed significant tourist business from Canada and Latin America, as well as Europe (Hanson et al. 2013; Sweig 2008, 252, 264; Drury 2005, 112).

The tightening of the embargo on 4 June 2019 aimed to target namely Cuba's booming tourism. It helped the country offset the weakness of its sugar exports and the reduction of Venezuela's economic aid, which fell from about US\$7.2 billion in 2014 to US\$2.3 billion in 2017. Tourism thus became the major asset in the Cuban leadership's bid for economic diversification and growth. To attempt to limit the negative effects of the latest US sanctions, on 11 July 2019, the head of the Cuban Ministry of Tourism (MINTUR) Manuel Marrero told the National Assembly of People's Power that the tourist industry needs to be reformed. Marrero also explained to the Cuban parliament that, compared to 2018, the United States' new travel bans would reduce the country's tourism revenue in 2019 by 20 percent. Speaking to his colleagues, Marrero claimed that the "resurgence of the blockade" is a reason to perfect Cuba's tourist marketing mechanisms (XinhuaEspañol 2019; Pedromo et al. 2019). In other words, the Cuban tourist industry had to use this opportunity to solve its inadequacies, by adopting more effective communication strategies, increase its internet presence and stimulate the flow of visitors from other countries. 


\section{Conclusion: Doomed to repetition?}

Those who do not know history are doomed to repeat it, the philosophical founder of modern conservatism Edmund Burke is oft-quoted saying. While this paper is far from offering any predictions on the success or the failure of the new sanctions against Cuba launched by the Trump Administration, Burke's expression provides us with a potent vignette through which we could object to the current Trump administration's lack of historical perspective in tackling the thorny Cuban question. While we live in a markedly different international setting from the times of Kennedy, Reagan, or Clinton's administrations, one can still wonder how today's right-wing US politicians directing Washington's Cuba policy could have overlooked various important history lessons of the past half-century. While free from that what President Carter called "inordinate fear of communism" (Pastor 1987, 50) that guided United States' foreign conduct during the Cold War, they prove there is more than one fear moving Washington's foreign policy-making towards their problematic neighbor. The communist threat might be outdated, but that of the Electoral College remains intact, as Trump's latest hemispheric policy appointees and actions suggest. Over the past half a century, Cuba has become a prime example of why sanctions are ineffective, especially when they penalize the population while targeting the ruling class.

Both the Torricelli and Helms-Burton laws of the 1990s have stimulated Cuban nationalist rhetoric, further legitimized the regime in times of economic trouble, failed to garner the support from Washington's traditional West European partners, and provided Havana with the symbolic yet politically significant unanimous backing of the United Nations General Assembly. Consequently, the continuing resilience of the regime helped make the small island nation the only country ever to transgress simultaneously both the Monroe and Truman doctrines (Eyler 2007, 32; Sanchez 2003, 357; Castro 1997, 105). As the history of the 60-year-long sanctions regime suggests, every time Washington tightened the bolts of the embargo it prompted Havana to consolidate its ranks and files from within and shop elsewhere to compensate for the lost economic opportunity. In 1960, the partial embargo introduced by Eisenhower and continued by Kennedy pushed the young Cuban revolutionaries toward the Soviet bloc. In the 1990s, the dissolution of the Soviet Union and the 
disbanding of the Council of Mutual Economic Assistance brought about the near-collapse of the Cuban economy. After Washington increased pressure on Havana with the 1992 Cuban Democracy Act and the 1996 Cuban Liberty and Democratic Solidarity Act, expecting the end of Fidel Castro's regime, Cuba found a wide-spectrum of foreign trade partners, ranging from Latin America through Western Europe to China, ready to support it economically and financially along its troubled road to survival in undermining Washington's coercive unilateral tactics.

Commentators in Cuba see the legal regulatory framework of US legislation towards their country as disregarding the desires of the $\mathrm{Cu}$ ban people at home. As for most Cubans on the island sovereignty and independence are basic values, the intent to restore US domination over Cuba went against a fundamental Cuban national interest (Castro Mariño 2002, 73; Mastanduno 2002, 305-311). As Bolton justified new tighter sanctions on Cuba and Venezuela's "Troika of Tyranny" in the western hemisphere, Cuba's new President Miguel Díaz-Canel responded with defiance, in line with his predecessors' well-tried formula. On 8 June 2019, as Diosdado Cabello, the head of Venezuela's Constituent National Assembly, ended his visit to Cuba, Díaz-Canel expressed Havana's readiness together with Caracas to defeat "the threats, the unfair sanctions and the blockade" (XinhuaNet 2019). A month later, he reiterated Cuba's support for Venezuela, posting on social media slogans in support of Maduro's "Bolivarian Revolution" in rebuking Washington's unilateral measures in violation of international law (Prensa Latina 2019).

Following the re-tightening of the embargo in June 2019, Havana is likely, as in the 1960s, to seek to step up relations with its old patron, Moscow. On 3 June, on Raúl Castro's 88th birthday, Russian Prime Minister Dmitri Medvedev lauded Raúl's "great personal contribution" to strengthening Russian-Cuban relations, which were developing dynamically in the "spirit of strategic partnership" (TASS 2019). In late July 2019, Russian Foreign Minister Sergei Lavrov traveled to Cuba to meet his counterpart Bruno Rodriguez Parrilla. Facing hardline Washington moves, Moscow and Cuba might see it fit to return to their Cold War-era relations. Sharply criticizing Trump's tighter restrictions on Cuba, the Russian Foreign Minister, stated Washington's approach was "unacceptable" and amounted to "unlawful economic coercion" (O'Connor 2019). More importantly, the increase in US pressure against Cuba and Venezuela 
seemed to aggravate hard-liners within the Russian military-political establishment. At a recent international security conference in Moscow, the head of the Main Directorate of the General Staff of the Russian Armed Forces Vice-Admiral Igor Kostyukov claimed that Washington was making considerable efforts to establish full control over Latin America, disregarding the norms of international law and taking no account of the negative consequences of its actions for regional stability and its closest partners. The Russian military intelligence chief went as far as to maintain that the United States could foment "colour revolutions in Cuba and Nicaragua" as well (RIA Novosti 2019). Thus, both overt and covert branches of Russian foreign policymaking seem to be sharpening their criticisms of the United States' regional role returning to the older division lines. Consequently, once again, just as 60 years ago, the present retightening of the US' sanctions regime against Cuba may jeopardize its domestic reforms. This might prompt Havana to seek to reclaim its position as a focal point of the renewed competitive coexistence between the world's major powers, United States and Russia, in an increasingly complex and multipolar post-Cold War world order.

\section{Addendum}

The inauguration of the 46th president of the United States, Joe Biden, on 20 January 2021 represents yet another test of the relations between Cuba and the United States for the eagerly anticipated post-COVID 19 world. A last-minute complication of the ties with the return of Cuba to the list of designated nations as 'states sponsors of terrorism' on 12 January 2021 by the Trump Administration (US Department of State 2021) might complicate Biden Administration's agenda vis-a-vis Cuba. At the same time, additional curbs in air traffic and the dwindling stream of tourists, caused by the COVID 19 pandemic, exacerbated the need for Cuban economic reforms. Havana's answer was a "complex" monetary reform (Deutsche Welle 2021) and "a likely irreversible step towards massively expanding the island's private sector" (Oppmann 2021), which seemed less probable a year ago. It remains to be seen, however, whether the events of the past year will lead to a new thaw in the relations between Washington and Miami. For one thing, with its aptly named Soberana 02 vaccine and the ability to muster "cutting edge science" (Grant 2021), Cuba sent a 
strong signal to its mighty adversary that whatever changes lay ahead, it is unlikely to wave goodbye to its self-reliance. As Moscow is watching from a distance, Miami's Cuban-American conservatives are recalculating their moves, and the Cubans on the island are hastily learning to embrace their newly minted market reforms, all eyes are now on Biden.

\section{Bibliography}

AJ 1960 (Arhiv Jugoslavije, Belgrade). Z. Grahek, Izveštaj o Kubu, 18 May 1960. KPR, I-5-b/61-1, Kuba.

AJ 1974. Podsetnik o Kubi i jugoslovensko-kubanskim odnosima, 20 February 1974. KPR I-5-b/61-3.

Anderson, J. 2019. Mexico, Cuba, and Trump's Increasing Preference for Punishment over Diplomacy. The New Yorker. 11 June 2019. Available at: https://www. newyorker.com/news/daily-comment/mexico-cuba-and-trumps-increasingpreference-for-punishment-over-diplomacy [18 January 2020].

Badella, A. 2014. American hýbris: US democracy promotion in Cuba after the Cold War - Part 1. International Journal of Cuban Studies 6(2), 157-188.

Bardach, A. 1994. Fidel Castro, the Vanity Fair Interview. March 1994. Available at: https://www.vanityfair.com/news/1994/03/fidel-castro-exclusive-interview [18 January 2020].

Brenner, P., Jiménez, M., Kirk, J, and LeoGrande, W. 2015. History as Prologue: Cuba before 2006 (1-33). In Brenner, P., Jiménez, M., Kirk, J, and LeoGrande, W. ed. A contemporary Cuba reader: The revolution under Raúl Castro. Lanham, MD: Rowman \& Littlefield.

Brenner P. and Castro Mariño S. 2015. Untying the Knot: The Possibility of a Respectful Dialogue between Cuba and the United States (277-291). In Brenner, P., Jiménez, M., Kirk, J, and LeoGrande, W. ed. A contemporary Cuba reader: The revolution under Raúl Castro. Lanham, MD: Rowman \& Littlefield.

Castro, M. 1997. Transition and the ideology of exile (91-105). In Miguel Angel Centeno. ed. Toward a new Cuba? London: Lynne Rienner.

Castro Mariño, S. 2002. U.S.-Cuban Relations during the Clinton Administration. Latin American Perspectives 29(4), 47-76.

CGED/MINREX 1962 (Centro de Gestión Documental del Ministerio de Relaciones Exteriores, Havana). Ministerio del Comercio Exterior (MINCEX). Declaración del gobierno de la República Popular de Polonia, 24 October 1962. Fondo EuropaPolonia Ordinario, Caja 1960-1976.

CGED/MINREX 1972. Discurso de Carlos Rafael Rodríguez en la XXVI sesión del Consejo de Ayuda Mutua Económica (CAME), MINREX (Direccion de Paises Socialistas), Consejo de Ayuda Mutua Económica CAME, Fondo CAME Ordinario, Caja 1970-73.

CGED/MINREX 1981. 5ta Conferencia internacional de directores de instituciones para la formación y elevación de la calificación de los cuadros del comercio exterior de los países miembros del CAME. Ponencia de Cuba, July 1981. Fondo CAME Ordinario, Caja 1981. 
CGED/MINREX 1984. Memorandum of Conversation between Fidel Castro and Romanian Prime Minister Constantin Dăscălescu, 13 November 1984. Fondo Europa-Rumania Ordinario, Caja 1978-86.

Chardy A. 1997. Mas Canosa Built Solid Foundation. Miami Herald, 24 November 1997.

CIA 1960 (CIA FOIA Reading Room [Online]). Central Intelligence Bulletin, Sino-Soviet Bloc Support for Cuba, 8 July 1960. Available at: https://www.cia.gov/library/ readingroom/docs/DOC_0000132622.pdf [18 January 2020].

CIA 1974. CIA Intelligence Memorandum, Cuba's US Policy: Ready for a Change, 23 July 1975. Available at: https://www.cia.gov/library/readingroom/docs/CIARDP85T00353R000100190003-3.pdf [18 January 2020].

CIA 1977. Frank Church, Delusions and Reality - The Future of United States-Cuba Relations, Report to the Senate Committee on Foreign Relations United States Senate on a Trip to Cuba, 8-11 August 1977. Available at: https://www.cia.gov/ library/readingroom/docs/CIA-RDP90G01359R000200060009-3.pdf [18 January 2020].

CIA 1986. Robert M. Gates, Impact of US Sanctions Against Nicaragua and Cuba, 7 January 1986. Available at: https://www.cia.gov/library/readingroom/docs/CIARDP90G01359R000200060009-3.pdf [18 January 2020].

Coltman, L. 2003. The Real Fidel Castro. New Haven, CT: Yale University Press.

CSDB 1975a. (Castro Speech Database [Online]). Fidel Castro interviewed by Izvestiya's A. Bovin, The Revolution is Advancing, 6 March 1975. Available at: http://lanic. utexas.edu/project/castro/db/1975/19750506.html [18 January 2020].

CSDB 1975b. Castro Sees Blockade Eventually Lifting, Benefiting U.S., 4 January 1975. Available at: http://lanic.utexas.edu/project/castro/db/1975/19750104.html [18 January 2020].

Deutsche Welle. 2021. Cubans wrestle with complex currency reform. 6 January 2021. Deutsche Welle. Available at: https://www.dw.com/en/cubans-wrestle-withcomplex-currency-reform/av-56143117 [13 March 2021].

DIA 1998. Defense Intelligence Agency, The Cuban Threat to U.S. National Security, 5 May 1998. Available at: https://fas.org/irp/dia/product/980507-dia-cubarpt.htm [18 January 2020].

Diaz-Briquets, S. and Perez-Lopez J. 1997. Refugee Remittances: Conceptual Issues and the Cuban and Nicaraguan Experiences. The International Migration Review 31(2), 411-437.

Dobson, A and Marsh S. 2005. US foreign policy since 1945. London: Routledge, 2005.

Domínguez, J. 1997. U.S.-Cuban Relations: From the Cold War to the Colder War. Journal of Interamerican Studies and World Affairs 39, 49-75.

Drury, A. 2005. Economic Sanctions and Presidential Decisions: Models of Political Rationality. Basingstoke: Palgrave Macmillan.

Ellis, A. 2019. Support for the embargo on the rise among Cuban-Americans, reveals FIU Cuba Poll. 10 Jan. 2019. Available at: https://news.fiu.edu/2019/support-forthe-embargo-on-the-rise-among-cuban-americans-reveals-fiu-cuba-poll [18 January 2020]

Erikson, D. Obama's Cuba Policy: The End of the 'New Beginning' (100-114). In Lowenthal, A., Piccone, T., and Whitehead, L. eds. Shifting the balance: Obama and the Americas. Washington, D.C.: Brookings Institution Press.

Eyler, R. 2007. Economic Sanctions: International Policy and Political Economy at Work. Basingstoke: Palgrave Macmillan.

Farber, S. 2011. Cuba since the revolution of 1959: A critical assessment. Chicago, IL: Haymarket Books. 
Fisk, D. 2000. Economic Sanctions: The Cuba Embargo Revisited (65-86). In Chan, S. and Drury A. eds. Sanctions as economic statecraft: Theory and practice. Basingstoke: Palgrave.

Fonzi, G. 1993. Who Is Jorge Mas Canosa. Esquire. January 1993, 86-89, 199-122.

Gordon, J. 2012. The U.S. Embargo against Cuba and the Diplomatic Challenges to Extraterritoriality. The Fletcher Forum on World Affairs 36(1), 63-79.

Grant, W. 2021. Optimism as Cuba set to test its own Covid vaccine. BBC. 16 February 2021. Available at: https://www.bbc.com/news/world-latin-america-56069577 [13 March 2021].

Haass, R. 1997. Fatal Distraction: Bill Clinton's Foreign Policy. Foreign Policy 108, 112-23.

Haney, P. and Vanderbush, W. 2005, The Cuban Embargo: The domestic politics of an American foreign policy. Pittsburgh, PA: University of Pittsburgh Press.

Hanson, D., Batten, D., and Ealey, H. 2013. It's Time For The U.S. To End Its Senseless Embargo Of Cuba. Forbes. 16 January 2013. Available at: https://www.forbes. $\mathrm{com} / \mathrm{sites} / \mathrm{realspin} / 2013 / 01 / 16 /$ its-time-for-the-u-s-to-end-its-senselessembargo-of-cuba/\#36dd2ba92347 [18 January 2020].

Huberman L. and Sweezy, P. 1969. Socialism in Cuba. New York: Monthly Review Press.

Huddleston, V. 2019. Our Woman in Havana: A Diplomat's Chronicle of America's Long Struggle with Castro's Cuba. New York: Overlook Press.

Huntington, S. 1997. The Erosion of American National Interests. Foreign Affairs 76(5), 28-49.

Hufbauer G., Schott, J., Elliott, K., and Oegg, B. 2007. Economic Sanctions Reconsidered. Washington, D.C.: Petersen Institute for International Economics.

IPN 1990 (Instytut Pamięci Narodowej, Warsaw). Kuba 1990 - prognoza, February 1990. BU 0449/16.

Jaffe, A. and Labott, E. 2014. Historic thaw in U.S. Cuba standoff. CNN. 17 December 2014. Avilable at: http://edition.cnn.com/2014/12/17/politics/obama-cubacastro-relations/index.html?hpt=hp_t1 [18 January 2020].

Kaplowitz, D. 1998. Anatomy of a Failed Embargo: U.S. Sanctions against Cuba. Boulder, CO: Lynne Rienner.

Lanvin, F. 1996. Asphyxiation or Oxygen? The Sanctions Dilemma. Foreign Policy 104, 138-153.

Lamrani, S. 2013. The Economic War against Cuba. New York: Monthly Review Press.

Landau, S. 2009. The Cuban Embargo: Nothing Succeeds Like Failure. CounterPunch, 30 October 2009. Available at: https://otherwords.org/cuban_embargo_ nothing_succeeds_like_failure/ [18 January 2020].

LeoGrande, W. 1998. From Havana to Miami: U.S. Cuba Policy as a Two-Level Game. Journal of Interamerican Studies and World Affairs 40(1), 67-86.

LeoGrande, W. 2000. Review of Peter Schwab's Cuba: Confronting the U.S. Embargo. The American Political Science Review 94(4), 999-1000.

LeoGrande, W. 2015. A Policy Long Past its Expiration Date: US Economic Sanctions against Cuba. Social Research: An International Quarterly 82(4), 939-966.

LeoGrande, W. 2019. Pushing on an Open Door? Ethnic Foreign Policy Lobbies and the Cuban American Case. Foreign Policy Analysis, orz015, Available at: https://doi. org/10.1093/fpa/orz015 [3 July 2019].

LeoGrande, W. and Kornbluh, P. 2014. Back Channel to Cuba: The Hidden History of Negotiations between Washington and Havana. Chapel Hill, NC: The University of North Carolina Press. 
Levine R. 2001. Secret missions to Cuba: Fidel Castro, Bernardo Benes, and Cuban Miami. Basingstoke: Palgrave Macmillan.

Martínez, P. 1997. Una Estrategia Internacional Contra la Ley Helms Burton. Foro International 37(2), 274-292.

Martínez-Fernández, L. 2014. Revolutionary Cuba: A History. Gainesville, FL: University Press of Florida.

Mastanduno, M. 2002. Extraterritorial Sanctions: Managing 'Hyper-Unilateralism' in U.S. Foreign Policy (295-323). In Patrick, S. and Forman, S. (eds.) Multilateralism and U.S. foreign policy: Ambivalent engagement. Boulder, CO: Lynne Rienner Publishers.

Morley, M. and McGillion, C. 2002. Unfinished Business: America and Cuba after the Cold War, 1989-2001. Cambridge: Cambridge University Press.

MNL 1960 (Magyar Nemzeti Levéltár, Budapest). Jenő Incze, Jelentés a Gazdasági Bizottságnak, 26 October 1960. XIX-J-1-j Kuba, TÜK, 1945-64, 9/a, 5d.

Muravchik, J. 1992. Exporting Democracy: Fulfilling America's Destiny. Washington, D.C.: AEI Press.

Naím, M. 2009. The Havana Obsession: Why All Eyes are on a Bankrupt Island. Newsweek. 22 June 2009. Available at: https://www.newsweek.com/moisesnaim-obssession-cuba-80307 [2 July 2019].

Nieto, C. 1999. Los amos de la guerra y las guerras de los amos: Cuba-Estados Unidos y America Latina. Bogotá: Ediciones Uniandes.

NSPM 2017. National Security Presidential Memorandum. Strengthening the Policy of the United States toward Cuba, 20 October 2017. Available at: https://www. federalregister.gov/documents/2017/10/20/2017-22928/strengthening-thepolicy-of-the-united-states-toward-cuba [18 January 2020].

O'Connor, T. 2019. Russia Promises More Support for Cuba, Including 'Military Technical' in Face of U.S. Pressure. Newsweek. 24 July 2019. Available at: https:// www.newsweek.com/russia-promises-more-support-cuba-including-militarytechnical-face-us-pressure-1451023 [18 January 2020].

Oppmann, P. 2021. After a long wait, Cuba opens the door to more capitalism. CNN. 9 February 2021. Available at: https://edition.cnn.com/2021/02/09/americas/ cuba-private-work-analysis-oppmann-intl/index.html [13 March 2021].

PAAA 1989 (Politisches Archiv des Auswärtigen Amtes, Berlin). Kurzinformation zur Republik Kuba, October 1989. MfAA ZR, 1923/13.

Pastor, R. 1987. Condemned to Repetition: The United States and Nicaragua. Princeton, NJ: Princeton University Press.

Pastor, R. 1994. The U.S. and the Caribbean: The Power of the Whirlpool. The Annals of the American Academy of Political and Social Science 533, 19-32.

Pedromo, J, Tellería, E, Pérez A., and González, A. 2019. Turismo cubano necesita perfeccionar sistema de comercialización. Trabajadores (Havana). 11 July 2019. Available at: http://www.trabajadores.cu/20190711/turismo-cubano-necesitaperfeccionar-sistema-de-comercializacion/ [18 January 2020].

Pérez-Stable, M. 2011. The United States and Cuba: Intimate enemies. New York: Routledge.

Petras, J. and Morley, M. 1996. Clinton's Cuba Policy: Two Steps Backward, One Step Forward, Third World Quarterly 17(2), 269-287.

Prensa Latina 2019. Cuba Reiterates Support for Venezuela against US Sanctions. Prensa Latina. 5 July 2019. Available at: http://www.cmhw.cu/en/ national/20547-cuba-reiterates-support-for-venezuela-against-us-sanctions [18 January 2020]. 
Putnam, R. 1988. Diplomacy and Domestic Politics: The Logic of Two-Level Games. International Organization 42(3), 427-60.

Radu, S. 2019. If Venezuela Falls, So Does Cuba, Experts Say. U.S. News \& World Report. 11 July 2019. Available at: https://www.usnews.com/news/best-countries/ articles/2019-07-11/cubas-dependency-on-venezuela-makes-it-vulnerable-toeconomic-turmoil [18 January 2020].

RIA Novosti 2019. SShA pytayutsya ustanovit' kontrol' nad Latinskoi Amerikoi, zaiavili v GRU. RIA Novosti. 25 April 2019. Available at: https://ria. ru/20190425/1553040019.html [18 January 2019].

Rockman, B. 1997. The Presidency and Bureaucratic Change after the Cold War (21-42). In Ripley R. and Lindsay J. eds. U.S. Foreign Policy after the Cold War. Pittsburgh, PA: University of Pittsburgh Press.

Sanchez, O. 2003. The Sanctions Malaise: The Case of Cuba. International Journal 58(2), 347-72.

Schoultz, L. 2009. That infernal little Cuban Republic: The United States and the Cuban Revolution. Chapel Hill, NC: The University of North Carolina Press.

Schwab, P. 1999. Cuba: Confronting the US embargo. New York: St. Martin's Press.

Skoug Jr, K. 1996. The United States and Cuba under Reagan and Shultz: A Foreign Service Officer Reports. Westpoint, CT: Praeger.

Sweig, J. 2008. Cuba: What Everyone Needs to Tnow. New York: Oxford University Press.

Sweig, J and Bustamante, M. 2013. Cuba after Communism: The Economic Reforms That Are Transforming the Island. Foreign Affairs 92(4), 101-14.

TASS 2019. Medvedev pozdravil Raulya Kastro s 88-letiem. TASS. 3 June 2019. Available at: https://tass.ru/politika/6503158, [19 January 2019].

US Department of the Treasure. 2019. Treasury and Commerce Implement Changes to Cuba Sanctions Rules, 4 June 2019. Available at: https://home.treasury.gov/ news/press-releases/sm700 [18 January 2020].

US Department of State. 2021. State Sponsors of Terrorism. Undated. US Department of State. Disponible en: https://www.state.gov/state-sponsors-of-terrorism/ [13 March 2021].

Vanderbush, W. 2009. Exiles and the Marketing of U.S. Policy toward Cuba and Iraq. Foreign Policy Analysis 5, 287-306.

White House 2018. Remarks by National Security Advisor Ambassador John R. Bolton on the Administration's Policies in Latin America, 2 November 2018. Available at: https://www.whitehouse.gov/briefings-statements/remarks-national-securityadvisor-ambassador-john-r-bolton-administrations-policies-latin-america/ [18 January 2020].

XinhuaEspañol 2019. Industria turística cubana sufre pérdidas millonarias por bloqueo de EEUU. Xinhua Español. 12 July 2019. Available at: http://spanish. xinhuanet.com/2019-07/12/c_138218969.htm [18 January 2020].

XinhuaNet 2019. Cuban president highlights unity between Cuba, Venezuela. XinhuaNet. 9 June 2019. Available at: http://www.xinhuanet.com/english/201906/09/c_138128377.htm [18 January 2019].

Yaffe, H. 2009. Che Guevara: The economics of revolution. Basingstoke: Palgrave Macmillan. EP 